\title{
Vilém Herold
}

\section{Na okraj Komentáře Jenka Václavova z Prahy k Aristotelově Politice z roku 1375}

Uvedeným Komentářem jsem se zabýval poprvé před více než třiceti lety a výsledky svého tehdejšího bádání jsem publikoval v časopisu Acta Universitatis Carolinae - Historia Universitatis Carolinae Pragensis v roce 1979 a potom v německém znění v periodickém sborníku Mediaevalia Philosophica Polonorum 1982. ${ }^{\mathrm{i}} \mathrm{V}$ poněkud jiném kontextu jsem se $\mathrm{k}$ tomuto dílu vrátil ještě $\mathrm{v}$ minulých letech $\mathrm{v}$ souvislosti s prŕípravou svých kapitol pro II. svazek Dějin politického myšlení, který má vyjít, věřím již brzy, v nakladatelství Oikúmené. Naposledy pak ještě jednou z podnětu konference, uspořádané za účasti našich předních filosofů a představitelů dalších humanitních oborů Katedrou filosofie Technické Univerzity v Liberci na památku prof. Jaroslavy Peškové v roce $2007 .{ }^{\text {ii }}$

Nebylo by tedy možná zapotřebí vracet se k textu, zapsanému nadto do rukopisného kodexu Národní (Univerzitní) knihovny v Praze přesně před 635 lety, kdyby k tomu téma našeho dnešního kolokvia Filosof jako zoon politikon. Role filosofie a filosofì v predmoderních společnostech přímo nevybízelo. Kromě toho rád využívám př́íležitosti zamyslet se společně v úzkém okruhu odborníků na antickou a středověkou

${ }^{\mathrm{i}}$ V. Herold, Komentár̆ M. Jenka Václavova z Prahy $\mathrm{k}$ Aristotelovu spisu „Politika“, in: AUC-HUCP 19/2, 1979, str. 19-40; Týž, Commentarium Magistri Johannis Wenceslai de Praga super octo libros 'Politicorum' Aristotelis, in: MPP 26, 1982, str. 53-77.

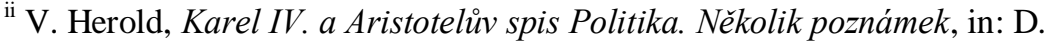

Krámský et al. (eds.), Humanitni védy dnes a zítra, Liberec 2007, str. 167-182. 
filosofii, kterými naše oddělení disponuje, nad některými tezemi a hypotézami, ke kterým jsem dospěl.

Dovolte mi, prosím, abych úvodem prripomenul a zrekapituloval hlavní fakta a závěry výzkumu, který jsme tehdy společně s kolegou Milanem Mrázem v návaznosti na 600. výročí úmrtí Karla IV. podstoupili. Bylo to při př́pravě studie pro jubilejní univerzitní sborník, kterou jsme chystali společně $\mathrm{s}$ dnes již bohužel zesnulým Zdeňkem Horským, ${ }^{i}$ kdy nás zaujala skutečnost, že dosud nebyla prakticky věnována skoro žádná pozornost souboru čtyř komentářo̊ k Aristotelovým spisům, jejichž autorem byl český profesor artistické fakulty pražské univerzity Jenek Václavův z Prahy. Také samotný autor těchto děl nebyl, s výjimkou dvou krátkých statí F. M. Bartoše a R. Holinky, skoro znám. ${ }^{\text {ii }}$ Rozhodli jsme se tehdy, věnovat pozornost rukopisu VIII G 30, kam byly v roce 1375 zapsány latinské komentáře k Aristotelovým spisům De caelo <et mundo>, De generatione et corruptione, De anima a Politica. U dvou z nich je autorství Jenkovo výslovně uvedeno, z dalších skutečností je však nesporné, že se týká i zbývajících dvou spisů. Samotný kodex byl patrně jedním z těch, které jejich autor Jenek odkázal koleji národa českého. ${ }^{\text {iii }}$ Komentování Aristotelových spisů patřilo jak známo k povinnostem profesorů artistické fakulty pozdně středověkých univerzit a lze předpokládat, že Jenek komentoval i další spisy Stagirity, třebaže bezpečný doklad máme již jen o jednom, o jeho nedochovaném komentáři

i V. Herold - Z. Horský - M. Mráz, Filozofie a přírodní vědy v době Karlově, in: Karolus quartus. Piae memoriae fundatoris sui Universitas Carolina d. d. d., Praha 1984, str. 249-270. (Sborník, který redigoval V. Vaněček, vyšel s mnohaletým zpožděním, protože tehdejší autority váhaly, zda je vůbec možné jej vydat!)

ii R. Holinka, K dějinám středověkého aristotelismu, Mistr Jenek z Prahy, in: Řád 9, 1943, str.78-79, F. M. Bartoš, M. Jenek z Prahy, rektor university Karlovy, in: JSH 9, 1936, str. 41-43.

iii Soudí tak J.Truhlár, Catalogus codicum manu scriptorum latinorum qui in c. $r$. Bibliotheca publica atque Universitatis Pragensis asservantur, I., Pragae 1905, str. 599. 
k Aristotelově Fyzice, který Jenek sám připomíná na začátku svého Komentáre $k$ De caelo <et mundo>. ${ }^{\mathrm{i}} \mathrm{K}$ bližšímu zkoumání jsem si tehdy vybral Jenkův Komentář k Politice, Milan Mráz k Aristotelově $O$ duši. ${ }^{\text {ii }}$

Připomeňme si však ještě napřed alespoň základní známá biografická data o autorovi těchto komentár̆ů: Jenek Václavův z Prahy (Iohannes Wenceslai de Praga) se v pramenech poprvé objevuje v roce 1366, kdy se stal z přímého rozhodnutí císaře Karla IV. jedním z šesti členů Karlovy koleje, zřízené pro mistry artistické fakulty, a to přímo při jejím založení dne 1. června. iii Setkáváme se $\mathrm{s}$ ním tedy již jako s profesorem této fakulty pražské univerzity. Je na ní dále doložen jako examinátor a promotor v letech 1367-1377, pokračoval na univerzitě obvyklým způsobem ve studiu teologie, $\mathrm{v}$ níž hodnosti bakaláře dosáhl $\mathrm{v}$ roce 1378 . Jako rektor pražské univerzity působil v letech 1382-1383, byl kanovníkem kaple Všech svatých i kanovníkem u sv. Víta v Praze (1380) a $\mathrm{v}$ roce 1385 dosáhl na pražské alma mater profesury teologie. Zemřel patrně někdy kolem roku 1400, když předtím odkázal svůj dům a větší počet knih (studentské) koleji národa českého, za což si vysloužil titul zakladatele a velkého dobrodince (koleje) českého národa (fundator Nationis Bohemicae et magnus benefactor). ${ }^{\text {iv }}$

Z prostého porovnání uvedených životopisných dat Jenkových se známými životopisnými daty tzv. Husových předchůdců, se nabízí (alespoň

i „Sicud dixi ingrediendo ad exposicionem libri Phisicorum “ Rkp.UK Praha VIII G 30, f. 1r.

ii Viz M. Mráz, Commentarium Magistri Johannis Wenceslai de Praga super De anima' Aristotelis, De gegenwärtige Zustand der Forschungsarbeit, in: MPP 26, 1982, str. 82-91; v rámci tohoto zkoumání však M. Mráz provedl určité základní srovnání i pokud jde o Jenkovy zbývající dva komentáře k př́rodní filosofii Aristotelově.

iii Statuta Collegii Karoli Quarti, ed. J. Tř́iška, Starši pražská univerzitni literatura a karlovská tradice, Praha 1978, str. 75.

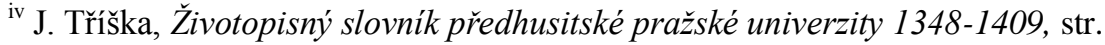
321-322. Citovaná slova o Jenkovi uvedl poslední předbělohorský rektor pražské univerzity M. Jan Kampanus (Calendarium beneficiorum Academiae Pragensia ... Anno 1616, ed. K. Hrdina, Praha 1949). 
teoretická) možnost kombinace jejich vzájemných kontaktů a setkání v tehdejší české intelektuální Praze. K nim ovšem nemáme žádný přímý pramenný doklad, ale považovat je a priori za vyloučené, by asi nebylo rovněž zcela správné. Snad bychom je mohli skromně předpokládat alespoň pokud jde o Vojtěcha Raňkova z Ježova a Matěje z Janova. Doložena je ale jen osobní vzpomínka Husova na Jenka v jeho výčtu již zemřelých českých profesorů teologie pražské univerzity, kde je uveden hned za Vojtěchem Raňkovým a společně ještě s Mikulášem Bicepsem, Mikulášem z Rakovníka, Mikulášem z Litomyšle, Štěpánem z Kolína, Janem Štěknou a Petrem ze Stupna. Hus pronesl tuto vzpomínku v kázání Confirmate corda vestra jako rektor této univerzity ve výroční den smrti jejího zakladatele Karla IV. v roce 1409. Charakterizuje v ní Jenka, možná trochu překvapivě, jako nejhbitějšího matematika (mathematicus promptissimus). ${ }^{\mathrm{i}}$ Snad v tom lze spatřovat Husovu vlastní vzpomínku na Jenkovo působení na artistické fakultě, kde Jenek mohl vykládat aritmetiku či geometrii, třebaže k tomuto nemáme jinak žádný přímý doklad. Nicméně samotné uvedení Jenkova jména v tomto výčtu skvělých pražských učenců je dostatečně výmluvné.

Vrat'me se však k Jenkovu Komentáři k Aristotelově Politice resp. k jeho historickému kontextu. Založením univerzity se i v Čechách posunulo těžiště politického myšlení do tohoto nového centra vzdělanosti. To se týká jak politické a sociální filosofie v užším slova smyslu, jejíž pěstování bylo předepsáno příslušnými statuty na artistické fakultě, tak širšího okruhu politického myšlení, souvisejícího často i s řešením otázek teologických a eklesiologických, ale i s úlohou univerzity v politických peripetiích tehdejší doby vůbec. Konečně nelze samozřejmě v tomto kontextu zcela vynechat ani právnickou fakultu pražské univerzity a posléze, od roku 1372 (do roku 1419), i samostatnou právnickou univerzitu v Praze, třebaže, jak plným právem kdysi konstatoval náš přední

${ }^{\mathrm{i}}$ Srov. Iohannes Hus, Positiones, recommendationes, semkneš, ed. A. Schmidtová, Praha 1958. str. 125-126. 
právní historik Jiří Kejřr, místem vzniku učených názorů na stát a právo nebyla a její ambice teoreticko-politické nebyly veliké. ${ }^{\mathrm{i}}$

$\mathrm{Na}$ artistické fakultě byly, tak jako na dalších středověkých univerzitách, základem výkladu Aristotelovy spisy, resp. jejich latinské překlady. To se týká v plné míře i výkladu ,praktické filosofie“, etiky, ekonomiky a politiky, jejichž cílem není tolik nalézání pravdy, jako je tomu u disciplín spekulativních, ale (návod k) jednání. Za základ výkladu zde sloužily Aristotelovy spisy Ethica Nicomachea a Politica a pseudoaristotelská Oeconomica. Je př́iznačné, že se jim v učebním plánu pozdně stř̌edověkých univerzit, a zejména i v Praze, věnovala značná pozornost. ${ }^{i i}$

Výklad se uskutečňoval nejen přímo na základě př́islušných Aristotelových latinských spisů, ale přednášející profesoři využívali k lepšímu vysvětlení a usnadnění pochopení i př́islušných komentářů $\mathrm{k}$ nim, vlastních nebo osvědčených cizích. To bylo naprosto běžné na všech středověkých univerzitách a komentáře $\mathrm{k}$ jednotlivým Aristotelovým dílům lze v hojném počtu doložit i v Praze. ${ }^{i i i}$ Totéž platí i pro základní Aristotelovo dílo pro středověkou politickou filosofii, jeho Politiku. ${ }^{\text {iv }}$ Recepce a interpretace tohoto spisu následovala $v$ Evropě bezprostředně po jeho překladu do latiny. Ǩadu jeho středověkých komentátorů zahajuje

${ }^{\mathrm{i}} \mathrm{J}$. Kejř, Stát, církev a společnost v disputacích na pražské universitě v době Husově a husitské, Praha 1964, str. 7-8.

${ }^{\text {ii }}$ Srov. F. Šmahel, Fakulta svobodných umění, in: Dějiny Univerzity Karlovy I, Praha 1995, str. 101-134, F. Šmahel, Zwei Vorlesungsverzeichnisse zum Magisterium an der Prager Artistenfakultät aus deren Blütezeit (1388-1390), in: F. Šmahel, Die Prager Universität im Mittelalter, Leiden 2007, str. 316-335, F .Kavka, Organizace studia na pražské artistické fakultě, in: AUC-HUCP, 8/1, 1967, str. 7-39.

iii J. B. Korolec, Středověké komentáře k Aristotelovým dilům na pražské universitě, in: AUC-HUCP 15/2, str. 31-51.

${ }^{\text {iv }}$ J. B. Korolec v citované práci (pozn. 13) zjistil jen v rukopisech Národní knihovny v Praze a Knihovny metropolitní kapituly v Praze celkem 7 komentářu $\mathrm{k}$ tomuto spisu, které byly nepochybně na pražské univerzitě ve středověku používány. Tento počet samozřjmě není konečný, bylo by třeba zahrnout další knihovní sbírky, kam se rukopisy používané v Praze postupně dostaly. Viz k tomu též další výklad. 
Albert Veliký a Tomáš Akvinský v 60. a 70.letech 13. století. ${ }^{i}$ Neúplný komentáŕ Tomášův, končící uprostřed III. knihy Aristotelova spisu, dokončil jeho žák Petrus de Alvernia, který napsal sám další komentář k témuž dílu. Další dva komentáře k Politice,pocházející ještě ze 13. století, Jiljího Ř́mského a Sigera z Brabantu, se nedochovaly a komentářem anglického filosofa Waltera Burleye (Gualterus Burlaeus) se dostáváme již do století čtrnáctého.

Zájem o Aristotelovu Politiku na pražské univerzitě, který se rozvíjí vlastně již od poloviny 14 . století, je tedy zájmem z historického či chronologického hlediska relativně velmi časným. Spadá do doby, kdy se $\mathrm{v}$ rámci latinské středověké filosofie politická věda právě v návaznosti na poznání aristotelských teorií teprve konstituuje, kdy dochází k určitému propojení Aristotelem inspirovaných teorií s dosavadní tradicí knížecích zrcadel a kdy se tato „nová“ disciplina vymezuje i vůči „legistům a dekretistům", tedy vůči dosavadní iurisprudenci, a to jako filosofická, protože filosofové mají učit jak mají být zákony tvořeny a jak mají lidé spolu žit v obci či království, aby byl zachován mír. Už v 60.letech 13. století, v době kdy dochází k postupnému poznávání př́slušných Aristotelových spisů v oblasti latinské filosofie, si Roger Bacon povzdechl nad mechanickým př́stupem iuristů, kteří neznají Platóna a Aristotela, ${ }^{\text {ii }}$ a Jiljí Ř́mský tuto kritiku jakoby podpořil, když legisty přirovnal k neučeným „politickým idiotům“ (ydiote politici), protože tradují zákony sine arte, tedy bez přihlédnutí $\mathrm{k}$ filosofii. ${ }^{\text {iii }}$

\footnotetext{
${ }^{\mathrm{i}}$ M. Grabmann, Die mittelalterlichen Kommentare zur Politik des Aristoteles, München 1941; C. Flüeler, Rezeption und Interpretation der Aristotelischen Politica im späten Mittelalter, Amsterdam 1992, 2 sv., P. Czartoryski, Wczesna recepcja Polityki Arystotelesa na uniwersitecie Krakowskim, Wrocław 1963.

${ }^{\text {ii }}$ Cit. dle D. de Lagarde, La naissance de l'esprit lä̈que au déclin du moyen âge, II., Louvain 1958, str. 14.

${ }^{\text {iii }}$ Srov. C. Flüeler, Rezeption und Interpretation der Aristotelischen Politica im späten Mitteallter, Amsterdam 1992, 2 sv. (uvedený citát: I, str. 7).
} 
Kompletní latinský překlad Aristotelovy Politiky byl v Praze k dispozici v knihovně koleje Karlovy již záhy po založení univerzity. Svědčí o tom dodnes kodex III. E 19, Národní (Univerzitní) knihovny v Praze, pocházející z přelomu 13.-14. století. Vzbudil zde nepochybně zájem, jak svědčí samostatný anonymní Prolog, a rovněž anonymní marginální a interlineární glosa, tedy forma nejstručnějšího komentáře, která jej provází. Na tyto texty u nás, také $\mathrm{v}$ souvislosti s jubilejním rokem Karla IV. 1978, záslužně upozornila Jaroslava Pešková. ${ }^{i}$ Jak pak prokázaly nejnovějši výzkumy švýcarského badatele Christopha Flüelera, vykazuje tento Prolog, který patrně vznikl v Praze ve druhé polovině 14. století, podobně jako zmíněný komentár̆ doprovázející překlad formou glosy (je psán stejnou písařskou rukou), již prrímou znalost Burleyova Komentáre $k$ Politice $\mathrm{z}$ roku 1342, $\mathrm{z}$ nějž cituje charakteristiku či definici obce včetně uvedení jejího autora. ${ }^{\text {ii }}$

Sám rozsáhlý Burleyův Komentáŕ $\mathrm{k}$ Politice, o němž budeme dále hovořit a který se dnes již v Praze nedochoval, je nicméně také doložen ve starém katalogu knih koleje Karlovy, sestaveném krátce po roce 1370, a to jako majetek právě této pražské univerzitní koleje. ${ }^{i i i}$ Anglický filosof Walter Burley byl přitom v Praze velmi populární. Předpokládalo se zatím, že to je zásluhou jeho po Evropě velmi rozšířené a populární sbírky De vita et moribus philosophorum, která je dodnes v českých knihovnách a archivech uchována $\mathrm{v} 36$ středověkých rukopisech a která se již v druhé polovině 14. století dočkala i staročeského překladu. ${ }^{\text {iv }}$ Nově se prokazuje, že se spojitost s naším kulturním prostředím mohla týkat i př́mo Burleyova

\footnotetext{
i J. Pešková, Problémy filosofického myšleni v Praze doby Karla IV., in: AUCHUCP, 21/1, 1981, str. 7-25.

ii In civitate, ut dicit Burlei, potest homo invenire sufficienciam ad vitam et ad regimen virtuosum, quam in aliis communitatibus non potest invenire, ut in communitate domus vel alicuis loci seu vici, rkp. UK Praha III E 19, f. III.r., Flüeler, Rezeption II, str. 82; k Burleyovu komentáŕi viz dále.

iii „Burley super Politicorum in papiris“ - Viz: J. Bečka - E. Urbánková, Katalogy knihoven Karlovy university, Praha 1948, str. 2, ordo VIII.

${ }^{\text {iv }}$ A. Vidmanová-Schmidtová, Burleyovy Životy starých filosofü a jejich české preklady, Praha 1962.
} 
Komentářre $k$ Aristotelově Politice. Burley totiž v době svého pařǐžského působení v letech 1310-1327 poslouchal na tamní univerzitě mj. i přednášky Pierra Rosiers (Petrus Rogerii), kterému později, když se tento muž stal papežem Klimentem VI., věnoval druhou redakci tohoto svého Komentářre. ${ }^{\mathrm{i}}$ Víme přitom o přátelských vztazích Karla IV. k tomuto jeho „vychovateli“", tedy pozdějšímu Klimentovi VI., a tak, i kdyby nebylo zmínky u Beneše Krabice z Weitmíle o Karlových studiích na pařížské univerzitě, spadajících do stejné doby, nemusíme snad vylučovat ani možnost, že se jmenované Burleyovo dílo mohlo dostat do Čech přímo určitým zprostředkováním Karla IV. nebo někoho z jeho doprovodu a tak se i ocitlo v knihovně jím založené koleje pražské univerzity, nesoucí jeho jméno, jejímž členem se v roce 1366 stal Jenek.

Jenkův Komentár $k$ Aristotelovu spisu Politica dosud nebyl, podobně jako žádný z dalších tří jeho komentár̆ů, zapsaných v kodexu VIII G 30 publikován, a to samozřejmě ztěžuje značným způsobem jeho celkové poznání i interpretaci, tím spíše, že je zapsán velmi zběžnou gotickou kurzivou (gothica cursiva currens), využívající nadto velkého množství konvenčních zkratek, šetřících úsilí tehdejšího písaře i drahou látku psací, jíž tehdy i papír byl. Z paleografického hlediska tak opravdu samotné přečtení či spíše dešifrování představuje velmi náročný úkol. Co bylo možno zjistit: V prvé řadě jsem konstatoval, že Jenkův Komentár $k$ Aristotelově Politice představuje velmi rozsáhlý text. V kodexu, kde jsou zapsány další tři Jenkovy komentáře $\mathrm{k}$ Aristotelovým dílům, zabírá největší počet folií (75 oproti 109 pro zbývající tři) a skromně lze odhadnout, že jeho samotný přepis by zabral kolem 400-500 normostran. To může být dáno jak délkou komentovaného Aristotelova textu, který se člení do osmi knih, tak i významem, jaký Jenek tomuto dílu přikládal. Na první pohled bylo jasné, že jde o komentář velmi důkladný. Dále bylo možno konstatovat, že komentár je presentován formou systematického

\footnotetext{
${ }^{\mathrm{i}}$ Dvěma redakcemi Burleyova Komentáře se zabývala A. Maier, Zu Walter Burleys Politik-Kommentar, in: A. Maier, Ausgehendes Mittelalter, I, Roma 1964, str. 93-99.
} 
postupného výkladu, navazujícího postupně na jednotlivé věty nebo odstavce Moerbekova latinského překladu Aristotelova díla, které se vždy úvodem zkráceně formou lemmat citují. Jedná se tedy o výkladový komentář modo expositionis, který probírá postupně celý Aristotelův text a ne jen vybrané významné otázky či kvestie, jak je tomu u komentářù modo quaestionum.

Výklad je nejen důkladný, podrobný a systematický, ale je podán se snahou o systematickou klasifikaci a členění pojednávané látky. Základem tohoto členění je osm knih Aristotelova textu. Každá kniha se dále člení na traktáty, ty na kapitoly, kapitoly na hlavní oddíly (partes principales) a ty ještě na pododdíly (particula). Tento způsob je důsledně dodržován v celém komentáři a lze již zde říci, že pomohl při nalezení zdrojů, z nichž Jenek ve svém Komentáři k Aristotelově Politice vycházel. Velmi silně totiž připomínal způsob komentování, za nějž se Walteru Burleyovi dostalo již ve středověku čestného titulu doctor planus et perspicuus a ještě v renesanci byl charakterizován jako doctor clarissimus. Sám Burley tento postup vysvětlil v dedikaci svého Komentáře $k$ Aristotelově Politice, kde zdůraznil, že jednotlivé knihy Aristotelova textu „rozčlení na traktáty, každý z nich na kapitoly, ty na hlavní oddíly a ty konečně ještě na pododdíly, aby Aristotelovo učení z řečeného spisu bylo k dispozici jasněji a rozlišeněji“ (,,ut sententia Aristotelis in dicto libro clarior et distinctior habeatur "). ${ }^{\mathrm{i}}$

Víme již, že jak překlad Aristotelovy Politiky, tak Burleyův Komentář k ní, byly k dispozici v Jenkově době v Karlově koleji pražské univerzity, jíž byl Jenek z rozhodnutí císaře Karla IV. členem, a proto nepřekvapí, že srovnání textů obou komentářů přineslo potvrzení jejich souvislosti, či přesněji řečeno potvrzení skutečnosti, že Jenek z Burleyova

\footnotetext{
i Jedná se o Burleyovu dedikaci komentáře k Politice Richardovi z Bury, biskupovi z Durhamu, který byl jeho příznivcem. Sám Burley zdůrazňuje, že tak již postupoval v komentáři k Etice Níkomachově a v jiných knihách. Poprvé na Burleye v tomto smyslu poukázal M. Grabmann Methoden und Hilfsmittel des Aristotelesstudiums im Mittelalter, München 1939, str. 51-52.
} 
komentáře ve svém díle vycházel. ${ }^{\mathrm{i}}$ Podobný postup, kdy se k výkladu na středověkých univerzitách využívalo již osvědčených textů významných filosofů, které byly upraveny resp. modifikovány pro potřeby daného učiliště, doplněny nebo naopak zkráceny, byl tehdy naprosto běžný. Vznikaly tak, někdy i anonymně, více či méně samostatné texty, které sloužily jako základ $\mathrm{k}$ výkladům i disputacím na př́slušné univerzitě a měly, někdy i po dlouhou dobu vliv na formování a ideovou orientaci studentů i profesorů daného střediska. ii Pokud jde o autorské zpracování, můžeme zde také uvést alespoň jeden příklad naprosto shodného postupu, kdy jiný soudobý autor použil také osvědčený Burleyův komentár̆, tentokrát k Aristotelově Etice Níkomachově. Jedná se o vynikajícího filosofa Alberta Rickmersdorfa Saského, Buridanova žáka, rektora univerzity pařížské a prvního rektora univerzity vídeňské, který snad působil jistou dobu i v Praze a vynikal zejména v logice, matematice a př́rodní filosofii. I on se ve svém komentáři k tomuto Aristotelovu dílu přidržel struktury a členění Burleyova, převzal z něj doslova nebo skoro doslova, aniž citoval, dlouhé pasáže, a přesto o jeho autorství nebo autorském př́inosu není zapotřebí pochybovat. ${ }^{\text {iii }}$

Pojetí ,,autorských práv“ bylo ve středověku velmi odlišné od praxe naší doby. Nemůžeme ovšem resignovat na pokus, stanovit míru závislosti i míru odchylek a konkrétního přínosu toho kterého autora ve

${ }^{i}$ Protože ani Burleyův Komentár k Politice nebyl dosud zpř́ístupněn tiskem, bylo nutno i zde vycházet jen $\mathrm{z}$ jeho rukopisné verze. $\mathrm{K}$ tomuto účelu byl využit rukopis Bibliotheca Amploniana Erfurt, sign. Q 319, kde je Burleyův text zapsán na f. 25r36v a 72r-128r. Opis pochází z roku 1394 a nemůže se tedy jednat o nyní nezvěstný opis pražský. Teprve vydání obou těchto děl umožní ovšem učinit přsesnější závěry.

${ }^{i i} \mathrm{~V}$ př́ípadech, kde nebyli jejich autoři známí, byly tyto typy výkladů rozšířeny pod označením jako např. Quaestiones Pragenses, Lectura Cracoviensis, Expositio secundum Petrum de Alvernia apod.

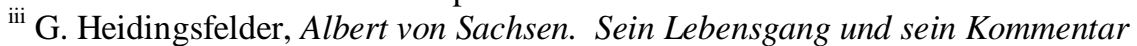
zur Nikomachischen Ethik des Aristoteles, Münster 1925, str. 71-86, J. Biard (ed.), Itinéraires d'Albert de Saxe, Paris-Vienne au XIVe siècle, Paris 1991; komentár Alberta Saského k Etice Nikomachově je shodou okolností zapsán v témže erfurtském rukopise Q 319, kde je zapsán Burleyův Komentár̆ k Politice. 
zkoumaném textu ve vztahu k dílu, z něhož se vycházelo. Pokusme se tedy o toto porovnání Jenkova Komentáře $k$ Politice a Burleyova Komentáře k témuž Aristotelovu spisu. Jak jsme již konstatovali, je shoda pokud jde o členění komentáře značná. Jenkovi zjevně názorný způsob prezentování Aristotelova textu, který zvolil Burley, vyhovoval a přidržoval se ho v celém díle. To přináší samozřejmě i značnou textovou závislost a je nesporné, že Jenek z Burleyova textu vycházel. Přesto lze shledat určité závažné rozdíly i po formální stránce. Burleyův systém členění je někde doveden až ad absurdum, a je nepochybně ku prospěchu věci, že jej Jenek systematicky v celém komentáři poněkud zjednodušuje. Nejen vynechává nebo zkracuje obsahové přehledy, které Burley vyčerpávajícím způsobem stále opakuje, ale vynechává i tzv. communes propositiones a zejména conclusiones, kde Burley jakoby př́liš závazně fixuje výsledky, k nimž na základě různých stanovisek pro et contra ve svém výkladu došel. ${ }^{\mathrm{i}}$

Už to může mít i určité ideové konsekvence, přesto jsou z našeho hlediska nejzajímavější věcné rozdíly ve formulacích a obsahu obou komentářů, protože prrinášejí svědectví o Jenkově přístupu a přínosu k dané problematice. Je třeba zde znovu připomenout, že nebylo možno vyčerpávajícím způsobem srovnávat znění obou celých rozsáhlých a jen rukopisně dochovaných komentářů, ale že závěry, které zde uvádíme, jsou učiněny jen na základě sond do dvou obtížně čitelných rukopisů, které jakkoli byly technicky a časově náročné a pracné - je proto třeba brát jako závěry předběžné. Teprve edice celých textů, Burleyova a Jenkova, umožní provést takové srovnání vyčerpávajícím způsobem.

Hned v 1.kapitole I. knihy nahrazuje Jenek Burleyův výklad o obci - státu (polis) a jeho účelu, vlastním podrobnějším výkladem. Oproti Burleyovi, který zde upozorňuje na nezávislost obce a její účel spatřuje ve shodě s Aristotelem spíše v zabezpečení potřeb k dobrému životu lidí, ${ }^{i i}$ zdůrazňuje Jenek, že obec nebo společenství obce je mezi ostatními

\footnotetext{
${ }^{\mathrm{i}}$ Podrobnosti viz V. Herold, Commentarium, str, 62-66.

ii Je to Burleyův text, který zná i stručný anonymní pražský komentáŕ k Aristotelově Politice z rkp.UK Praha III E 19.
} 
společenstvími přednější, nebot' tvoří určitý celek. Protože každý celek, který zahrnuje v sobě něco jiného je přednější, než toto zahrnuté, je také společenství obce, kterou se rozumí, jak Jenek zdůrazňuje, jak město tak království, (tedy) politické společenství (communitas politica), nejpřednější a zahrnuje v sobě přednější dobro a směřuje k němu, protože obecné dobré je přednější než dobro jednotlivce (intendit bonum commune, quod est melius boni unius). ${ }^{\mathrm{i}}$

Tato ukázka Jenkova postupu ze samého začátku textu není ojedinělá a lze konstatovat, že podobně samostatně přistupuje pražský filosof na mnoha dalších místech svého výkladu Aristotelova textu. Ani zde se totiž otrocky nepřidržuje Burleyova Komentáře k němu, třebaže z něj vychází. Zastavme se však ještě alespoň u některých významnějších zjištěných odlišností. K těm patří bezesporu definice politické vědy (scientia politica) uvažovaná v komentáři k začátku IV. knihy Aristotelovy Politiky, v níž se Jenek naopak přidržuje těsněji Aristotelova řešení než Burleyova, když uvádí, že této disciplině náleží jako o svém předmětu zkoumat, jaká je nejlepší ústava, třebaže jí nemůže být dosaženo, podobně jako v medicině, jejímž předmětem je zdraví, je třeba zkoumat, jaké je nejlepší zdraví, třebaže ho nikdo nemůže mít či dosáhnout. ${ }^{\text {ii }}$

Zvlášt' významné jsou diference Jenka oproti Burleyovi v komentáři k III. knize Aristotelovy Politiky, kde tento antický filosof vykládá pojmy ústavy, obce a občana, zabývá se otázkou rovnosti či nerovnosti občanů, tím kdo má vládnout a poměrem vlády (vládce) k zákonům. Jenek se důkladně zabývá touto problematikou v 2. a 3 . kapitole posledního traktátu svého komentáře III. knihy Aristotelovy Politiky v návaznosti na Aristotelův text, počínající slovy: „Začátkem zkoumání jest otázka, zda by bylo lépe aby vládl nejlepši muž, či nejlepši

\footnotetext{
i Jenek: rkp. UK Praha VIII G 30, f. 110r; Burley, Bibliotheca Amploniana Q 319, f. 25va.

${ }^{i i}$ Komentář se vztahuje k místu 1288 b 21; Burleyovu definici otiskl S. H. Thomson, Walter Burley on Aristotle's Politics, in: Mélanges Auguste Pelzer, Louvain 1947, str. 578.
} 
zákony “i Jenek, podobně jako Burley uvádí nejprve věrně Aristotelovy důvody pro vládu jednotlivce nebo mnohých a potom pro vládu zákona. Pak upozorňuje, že se Aristotelés vrací k původně postavené otázce $\mathrm{v}$ textu, kde se píše: „Některým se zdá, že neni ani přirozeno, aby jeden vládl nad všemi občany tam, kde se obec skládá ze stejných"“ ii

Jenek nejprve poznamenává, že se zde Aristotelés vrací k otázce, zda je lepší, aby vládl král nebo zákon, nebo oba. Opakuje jeho stanovisko, že je lepší, aby vládl zákon než král a pokračuje: vláda má být podle zákona, nebot' za předpokladu rovnosti občanů jak přirozené, tak co do postavení, je nespravedlivé, aby se podíleli na statcích nerovným způsobem. Jestliže jeden $\mathrm{z}$ občanů nemá více vrozené vlohy $\mathrm{k}$ tomu, aby vládl ani aby byl poddaným, je třeba a je spravedlivé, aby se občané ve vládě vyrovnali, což se bude díti postupně na základě rovnosti a podle správného řádu. Řád je však zákon. Mají tedy vládnout podle zákona, zákon je to, čím se musí rídit, podle správnosti zákonů mají soudit jako jejich služebníci a strážci (observatores et ministri legis), nebot' rád je ustanovil a oni jsou jeho služebníci (ministri legis). Zákon je totiž nad nimi, přičemž se zákonem rozumí všeobecný řád (rectitudo generalis). A tak se ukazuje, že má vládnout zákon a lze učinit závěr, že zákon má vládnout prostě - bez všeho dalšího (simpliciter principari). iii

Tuto myšlenku rozvádí Jenek dále. Zdůrazňuje, že Aristotelés záměrně chce, aby zákon takto bez dalšího vládl, a vysvětluje, co jest považovati za zákon: jsou to obecné zákony, ustanovené lidmi (leges universales ab hominibus instituti), a správnost soudícího rozumu (rectitudo intellectus iudicantis) bez jakéhokoli prrimíšení smyslové žádostivostí (absque aliqua admixtione apetitus sensitivi). V př́ípadech, určených ustanoveným zákonem a v těch, kde se dá tento zákon použít, má se soudit podle zákonů ustanovených lidmi. $\mathrm{V}$ ostatních prrípadech se má

\footnotetext{
${ }^{\text {i }}$ Aristoteles, Politica 1286 a 7, český překlad A. Kříže in: Aristotelés, Politika, Praha 1939, str. 106.

ii Aristoteles, Politica 1287 a 8, český překlad A Kř́̌že tamtéž, str. 109.

iii Iohannes Wenceslai, Commentarium, rkp. UK Praha VIII G 30, f. 138r-138v.
} 
soudit podle čistého rozumu (secundum intellectum purum) bez přimíšení smyslových žádostí. A takový rozum je možno charakterizovat jako zvláštní zákon (lex particularis). Zákon má tedy vládnout prostě - bez všeho dalšího, přičemž se zákonem rozumí jak zákon obecný, ustanovený lidmi, tak zákon zvláštní. ${ }^{\mathrm{i}}$

Na tomto místě náš komentátor, spíše výjimečně, uvádí delší přímý citát z Aristotelovy Politiky, z níž jinak cituje jen lemmata o dvou až třech slovech, udávající začátek textu, $\mathrm{k}$ němuž následuje výklad komentáře. Píše zde: „Proto říká v textu Aristoteles: 'Ten tedy, kdo káže, aby vládl zákon, káže, jak se zdá, aby vládl jenom Bůh a rozum. Kdo však žádá, aby vládl člověk, přidává ještě zvíře', poněvadž spojuje živočišný ráz smyslového života s rozumem, a potom ř́ká, že: zákon jest rozum bez žádostivosti. “ii Jenek pak ještě na konci výkladu k III. Knize uzavírá, že králem je ten, kdo žije podle rozumu a jako ztělesnění nejsprávnějšího zákona, ten však, kdo se v něčem pro vášnivou žádostivost smyslů od toho odkloní, ihned ztráci jméno krále. A tak mnozí jsou sice ctěni jako králové, avšak popravdě nejsou králi ale tyrany. ${ }^{\text {iii }}$

Tyto pozoruhodné pasáže jsou převzaty téměř doslovně z Burleyova komentáře iv Jenek jen na některých místech text ještě o něco více zdůrazňuje, např. navíc opakuje, že lex debet simpliciter principari a vynechává opatrnější Burleyovo pokud možno - prout possibile. Burley si patrně byl vědom toho, že uvedené pasáže a závěry mohou znít nebezpečně a proto připojuje na jednom místě v komentáři III. knihy, které jim předchází jakési captatio benevolentiae, znějící takto: „Dưvěrná láska občanů ke králi a důvěrná svornost mezi občany čini království nejsilnějšim, jak je dnes zřejmé o králi Anglie <tj. Eduardu III.>, diky jehož vynikající ctnosti je největši svornost mezi anglickým lidem, nebot’ každýje

\footnotetext{
${ }^{\mathrm{i}}$ Iohannes Wenceslai, Commentarium, rkp. UK Praha VIII G 30, f. 138v.

ii Iohannes Wenceslai, Commentarium, rkp. UK Praha VIII G 30, f. 138v.; český překlad A. Kř́iže: Aristoteles, Politika, str. 109 (Cf. Aristoteles, Politica, 1287 a 30sqq.).

iii Iohannes Wenceslai, Commentarium, rkp. UK Praha VIII G 30, f. 139v.

${ }^{\text {iv }}$ V rkp. Erfurt Ampl. Q 319 se nacházejí na f. 84vb - 87ra.
} 
spokojen se svým místem pod králem. “i Dalo by se očekávat, že Jenek, který doslova uvádí věty, které této pasáži u Burleye bezprostředně předcházejí, obmění na tomto místě text ve prospěch českého krále a císaře římského Karla IV. Avšak Jenek tuto pasáž zcela vynechal. Lze snad v tom spatřovat i doklad o relativně tolerantním duchu, který vládl na pražské univerzitě té doby i další doklad o relativně tolerantním přístupu Karlově (který jsme již mohli zaznamenat ve vztahu panovníka k Milíčovi z Kroměřiže, když tento císaře označil za Antikrista) a umožňoval přicházet a vystupovat $\mathrm{s}$ názory, jež by si v jiném kontextu bylo jen velmi těžké představit.

Je nesporné, že sám Burleyův Komentár $k$ Aristotelově Politice, který se snad z podnětu Karla IV. dostal do Prahy, je pozoruhodným dílem politického myšlení a politické filosofie své doby, která byla takto v pražském kulturním a univerzitním prostředí relativně záhy představena v plné šíři své problematiky. Je zde třeba důrazně připomenout, že je to jen shoda okolností, že ve své době právě toto tak populární a rozšířené dílo nebylo vydáno - a to ani $\mathrm{v}$ počátcích knihtisku ani později. To vedlo k tomu, že Burleyův Komentář unikl pozornosti pozdějších historiků politického myšlení. ${ }^{i}$ Počet dochovaných středověkých rukopisů Burleyova Komentáre v počtu 36 převyšuje přitom počet středověkých

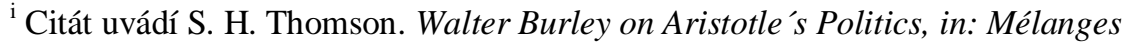
Auguste Pelzer, Louvain 1947, str. 578-579 na základě rkp. Oxford, Balliol College f. 183vb-184ra. Text se vztahuje k pasáži Aristotelovy Politiky 1284 b 33, která je traktována v Jenkově komentáři v rkp. UK Praha VIII G 30 na f. 136v. ii Např. i oproti Komentáři $k$ Politice, považovanému až donedávna omylem za dílo Jana Buridana, protože pod tímto autorským označením vycházel opakované v řadě starých tisků, třebaže jej sepsal Nicolas de Vaudémont (viz dále). Pokud jde o traktování v dějinách politických teorií, není např. ve starší standardní rozsáhlé šestisvazkové př́ručce R. W. a A. J. Carlylea, A History of Medieval Political Theory in the West, Edinburgh 1903-1936, o Burleyovi ani zmínka a v nové reprezentativní príručce J.H. Burns (ed.), The Cambridge History of Medieval Political Thought c. 350 - c. 1450, Cambridge 1988, je stále Burley zmíněn jen ve dvou větách, oproti obvykle rozsáhlému pojednání politických teorií Marsiliových a Ockhamových. 
rukopisů spisu Defensor pacis, Marsilia z Padovy! Počty dobových opisů ale vždy vypovídají o soudobém vlivu toho kterého středověkého díla. Kdybychom chtěli tuto tezi ještě vyhrotit, mohli bychom říci, že v moderním bádání o dějinách středověkého politického myšlení tak byla větší pozornost paradoxně věnována politickému myšlení na dvoře Karlova oponenta Ludvíka Bavora v Mnichově, než politickému myšlení v okruhu přeci jen daleko významnějšího pražského panovnického dvora. Bylo to přitom do značné míry jen proto, že Marsiliův Defensor byl vydán dokonce souběžně ve dvou moderních kritických edicích $(1928,1932)$ a tedy dobře znám, takže se jím zabývá velmi důkladně každá příručka dějin středověké politické filosofie, zatímco Burleyův a Jenkův Komentář zůstal ,zaklet v rukopisech" a tomuto bádání tedy nepř́ístupný.

Jenek, jehož dílo bychom mohli podle zavedeného úzu nazvat či charakterizovat jako Commentarium Iohannis Wenceslai de Praga in octo libros Politicorum Aristotelis secundum expositionem Gualteri Burlaei $\mathrm{z}$ díla anglického myslitele nepochybně poměrně věrně vyšel, přesto vytvořil bezesporu nový text komentáře. Převzal sice mnohé Burleyovy myšlenky jako své vlastní a tak vlastně i neprrímo dále přispěl k širrené tam obsažených idejí, zároveň ale výklad alespoň na některých místech významně modifikoval, doplnil či pozměnil. Jeho spis měl nejen bezprostřední vliv na univerzitní posluchače, ale možná i na panovnický dvůr. Kromě toho Jenkův text posloužil i za základ dalších výkladů k Aristotelově Politice na pražské univerzitě i na dalších univerzitách, kam studenti a absolventi z Prahy přicházeli. Přesnější posouzení této problematiky je však prakticky nemožné vzhledem $\mathrm{k}$ dosavadnímu stavu zpracování pramenného materiálu.

Zatím musíme tedy vzít zavděk s pracovní tezí, podle níž lze plným právem předpokládat určitý vliv nejen Burleyův ale i Jenkův na početnější rodinu komentářů $\mathrm{k}$ Aristotelově Politice $\mathrm{v}$ rukopisech pražské provenience, dochovaných i ve sbírkách, pocházejících z Prahy a

${ }^{\mathrm{i}}$ C. H. Lohr, Medieval Latin Aristotle Commentaries, II, Authors $G-I$, in: Traditio 24 (1968), str. 187. 
užívaných $\mathrm{v}$ univerzitních střediscích - v Polsku ale i v dalších - kam studenti a absolventi z Prahy přicházeli. ${ }^{\mathrm{i}}$

Je však možno se pokusit porovnat některé zajímavé závěry Burleyovy a Jenkovy, které jsme presentovali, s tím co přinášejí jiné známé komentáře k Aristotelově Politice. Týká se to zejména závěru o závaznosti zákona pro vládce, z III. knihy Aristotelovy Politiky, který jsme se snažili představit. Tomáš Akvinský, jehož Komentář končí na začátku III. knihy, k danému místu nedošel. Petrus de Alvernia, který tento komentár̆, snad vintencích Tomášových dokončil, pojednává tuto otázku velmi akademicky, a i když v průběhu výkladu uvažuje obě možnosti, dochází nakonec k opačnému závěru, že totiž je lepší, když vládne dobrý muž, než zákon (melius est principari bonum virum quam legem). ${ }^{\text {ii }}$ Pražský komentár̆ Jindřicha Tottinga z Oyty nebyl dosud podroben podrobnější analýze. Lze konstatovat, že je velmi stručný a řešením dané otázky se snad nezabývá. iii

Zdá se, že Jenkovu a Burleyovu řešení se nejvíce přibližuje rozsáhlý komentář sepsaný ve formě kvestií, který byl až donedávna považován za komentář Jana Buridana. Byl totiž pod jménem tohoto pařížského filosofa vydáván opakovaně už od začátku 16. století a ještě v 17. století ve starých tiscích a teprve C. Flüeler na základě rukopisných výzkumů nedávno prokázal, že jeho skutečným autorem je jiný pařŕžský filosof druhé poloviny 14. století, Nicolaus de Waldemonte (Nicolas de Vaudemont). ${ }^{\text {iv }}$ Př́stupnost tohoto díla i určitá proslulost Buridanova

\footnotetext{
${ }^{\mathrm{i}}$ Viz k tomu citované práce P. Czartoryského a C. Flüelera, které upozorňují na vliv Burleyův, ale vliv Jenkův nemohly zatím na základě dosavadního bádání rozlišit. Zejména by bylo třeba prozkoumat rozsáhlý pražský anonymní Komentár $k$ Aristotelově Politice zapsaný kolem roku 1454 do rkp. UK Praha X F 18, který vykazuje jistou př́ibuznost $\mathrm{s}$ textem Jenkovým. To se týká i komentářu $\mathrm{k}$ Politice, zapsaných v rkp. BJ Kraków 513 a 675, na něž jako zpř́zněné s Burleyem upozornil právě Czartoryski, str. 183sqq.

ii Komentáŕ Petra de Alvernia vydán in: Thomas Aquinas, In octo libros Politicorum Aristotelis expositio, ed. R. M. Spiazzi, Taurini 1966, str. 179-182.

iii Posuzoval jsem podle rkp. UB Leipzig 1413, srov. f. 165ra-165rb.

iv Anonymně vyšel ještě v inkunabuli v Paříži roku 1489, pod Buridanovým jménem ale tamtéž 1513 a ještě 1640 v Oxfordu; k autorskému určení viz Flüeler,
} 
(který byl mj. učitelem Mikuláše z Oresme, překladatele Aristotelovy Politiky do francouzštiny pro potřeby panovnického dvora), jemuž bylo připisováno, vzbuzovala $\mathrm{v}$ historicko-filosofickém bádání zájem o ně. $\mathrm{V}$ „Buridanově“ komentáři byl spatřován, ne bez důvodů, jeden ze zdrojů novověkých politických teorií (tak soudil např. už v 19.století francouzský politik, úzký spolupracovník Thierse, a překladatel Aristotela do francouzštiny Barthelémy-Saint Hilaire.) V citovaném komentáři jsou $\mathrm{k}$ dané otázce probírány důvody pro a proti a dochází se k dvěma pozoruhodným závěrům. První zní, že je lepší aby vládl kníže, druhý závěr - conclusio secunda uvádí, že v moderní době je jednoduše lepší, aby obci vládl dobrý zákon bez knížete než nějaký kníže bez zákona (temporibus modernis simpliciter melius est civitatem regi bona lege sine principe quam quocumque principe sine lege). ${ }^{\mathrm{i}}$

Zdroje tohoto př́stupu je však možno hledat ještě dále v historii, příznačně mezi představiteli latinského averroismu. Čelný představitel tohoto směru byl pařižský filosof Siger z Brabantu, který napsal komentář k Aristotelově Politice, který se nedochoval. Svědectví o výkladu tohoto „nejskvělejšího filosofa“ a jeho ohlasu však zachoval jeho žák Pierre Dubois, později právník Filipa Sličného. Ten zachoval i jedinou autentickou tezi z jeho výkladu: je mnohem lepší, aby obci - státu vládly správné zákony než řádní muži. ${ }^{\text {ii }}$ Je to právě ten závěr, který oproti Burleyovi, který opatrněji požadoval, aby tomu tak bylo pokud možno, Jenek tak zdůraznil tím, že napsal, aby tomu tak bylo bez všeho dalšího. Latinský averroismus, radikální aristotelismus či v tomto př́padě politický averroismus, je ostatně směr, jehož reprezentantem byl i Marsilius z Padovy, „,homo magis aristotelicus quam christianus “. (Pokud jde o spis Defensor pacis, patrně i svou spoluprací s dalším jeho představitelem

Rezeption und Interpretation, II, str. 39. Tento autor podle mého přesvědčení i docela přesvědčivě prokázal, že Buridan pravděpodobně Aristotelovu Politiku ani neznal!

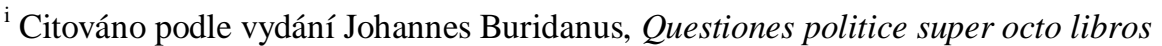
Politicorum Aristotelis confecte, Parisius 1513, f. 34rb-35ra.

${ }^{\text {ii }}$ Srov. Grabmann, Die mittelalterlichen Kommentare, str. 24. 
Janem z Jandunu, popř. Pierrem d'Abano.) ${ }^{\mathrm{i}}$ Pokud jde o Burleyovo stanovisko k latinskému averroismu, není možná zcela podstatné, zda jej můžeme za stoupence tohoto směru, jak se $\mathrm{k}$ tomu na základě rozboru jeho děl přikláněli Anneliese Maier a Zdzislaw Kuksewicz, ${ }^{\text {ii }}$ považovat, či ne. Možná, že jeho komentář k Politice bychom opravdu mohli za určitý projev politického averroismu přijímat. Se značnou dávkou jistoty však můžeme zde konstatovat, že „moderní“ politická teorie se tak - jinou cestou - dostala mimo mnichovský okruh i do okruhu pražského císařského dvora.

Závěrem není možno nepoukázat alespoň na některé možné souvislosti Jenkova díla s ideovým vývojem české společnosti doby předhusitské a husitské. Podle mého názoru se jedná přinejmenším o tři kontexty, které se nabízejí k prrípadnému bližšímu prozkoumání:

Za prvé: poukázat blíže na možnou iniciační roli Karla IV. a zabývat se eventualitou, zda a jakou stopu mohla zanechat, asi i francouzskými zkušenostmi iniciovaná znalost Aristotelovy Politiky (a komentářů k ní), pokud ji na základě všeho řečeného snad můžeme předpokládat, v politickém programu, zákonodárném úsilí a př́padně i praktické politice tohoto českého krále a římského císaře.

Za druhé: zabývat se otázkou, zda striktní pojetí priority vlády zákona v Jenkově pojetí, navazující na Aristotela, může nějak souviset se zdůrazněním závaznosti „,první pravdy“ (regula generalis, principalis) u Matěje z Janova v jeho Pravidlech Starého a Nového Zákona, či potom dokonce ,zákona Božího“ u Husa a v husitství, zdůrazňuje-li Jenek, podobně jako potom Hus tuto prioritu zejména pokud jde o mravní předpoklady vládcovy.

\footnotetext{
${ }^{\mathrm{i}}$ Pokud jde o spolupráci Jana z Jandunu viz G. de Lagarde, La naissance de l'esprit laïque au déclin du moyen âge, III, Le Defensor pacis, Louvain 1970, str. 9sqq.

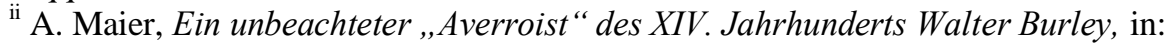
Medioevo et Rinascimento, Studi in onore di B.Nardi, Firenze 1955, Z.Kukesewicz, The Problem of Walter Burleys Averroism, in: Studi sul XIV secolo. In memoria di Anneliese Maier, Roma 1981, str. 341-377.
} 
Za třetí: zkoumat eventuálně i možnost zda Jenkovo zdůrazňování toho, že v obci je obecné dobro lepší než dobro jednotlivcovo (bonum commune est melius boni unius) nemůže předjímat či souznít s některými představami filosofického realismu nebo jeho krajní podoby té doby, zvláště víme-li, jaký ohlas toto tvrzení Wyclifovo (z jeho traktátu $D e$ universalibus, kde přímo vyvozuje, že neúcta $\mathrm{k}$ universáliím je prŕíinou všeho současného zla) pak nalezlo na pražské univerzitě a při prŕípravě husitského programu. 